\title{
Science Fair Winners
}

\section{Summary of the AMS Participation in the 1991 International Science and Engineering Affiliated Fairs, 5-11 May 1991}

The Orange County Convention and Civic Center in Orlando, Florida, hosted the 42nd International Science and Engineering Fair (ISEF) on 5-11 May 1991. Over 60 professional scientific, engineering, and federal organizations provided judges to administer spe-

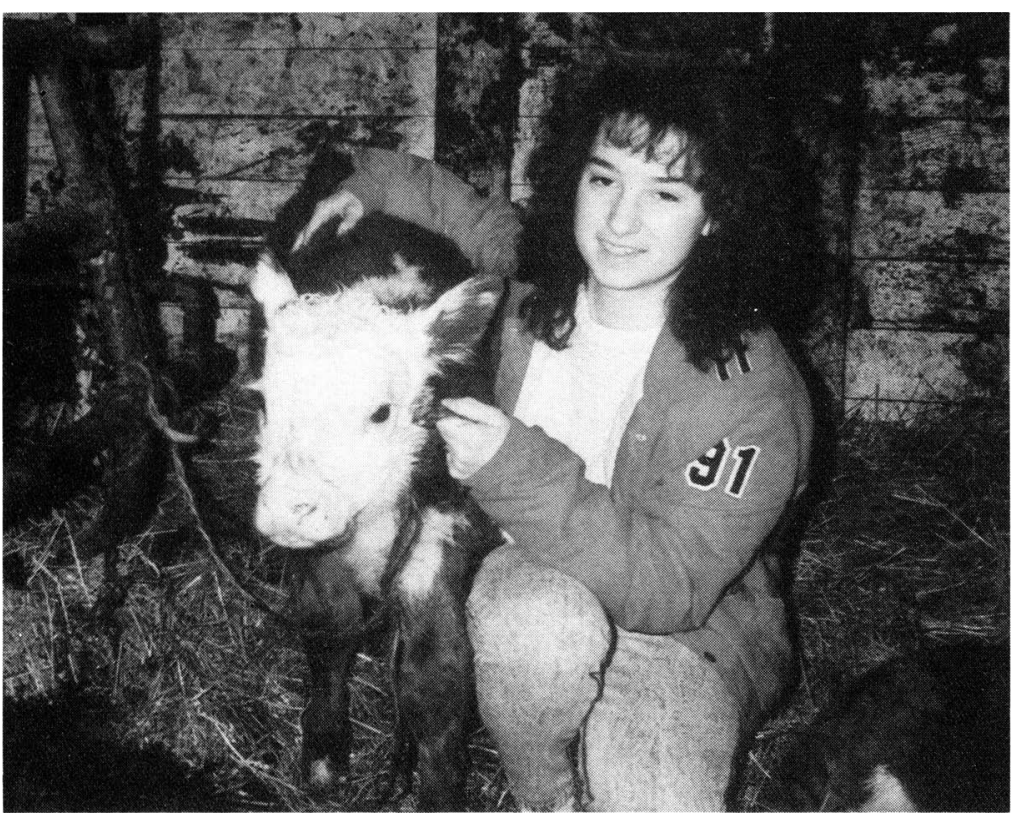

Kristy L. Edwards is the AMS special award winner for the best atmospheric science exhibit at the International Science and Engineering Fair for her project, "Effects of the 1988 Drought on Milk Production." mined. pared closely with those in recent years. Project content this year was more competitive, requiring additional, detailed evaluation time, and multiple interview rounds before the three finalists were deter-

First-Place Award: Kristy L. Edwards, 17, a senior at Tuscarawas High School in Soarville, Ohio, received the AMS special award for the best atmospheric science exhibit at the ISEF. Edwards work was on the "Effects of the 1988 Drought on Milk Production." Edwards developed a temperature-humidity (TH) stress index tailored for use with dairy herds. She modified a National Weather Service index for the general public and calibrated it to separate dairy-herd milk production datasets. She accomplished this by running sensitivity analyses on the $T H$ index equation and interactively adjusting to statistically optimize the correlation of TH index to milk production for several herds; these included herds at her farm and at the Ohio Agricultural Research and Development Center (OARDC) during the 1988 drought. The TH stress index can be an important tool to stabilize milk production and maintain dairy herd income. Edwards' work showed considerable insight and demonstrated unique practical utility, ranking her among the top AMS ISEF first-place winners in recent years for over-all excellence. Edwards received $\$ 250$ and a certificate of achievement from AMS headquarters.

cial awards at the ISEF. The AMS judging team consisted of Bart Hagemeyer and Michael Sabones, both of the National Weather Service Office (NWSO) in Melbourne, Florida, and Lt. Col. Charles Holliday of the Air Force Global Weather Central, Offutt Air Force Base, Nebraska.

The ISEF featured 748 finalists from 395 affiliated, regional fairs in the United States and its territories, as well as seven foreign countries. Atmosphere-related projects (totaling some 15 exhibits) covered a wide range of topics, including drought, sunspot activity correlation, global warming, lightning, synoptic forecasting, satellite imagery analysis, the EI Niño/Southern Oscillation, and acid rain. The percentage of atmosphere-related topics to total entries $(2 \%)$ com-
Second-Place Award: Amy Lantis, 16, a junior at Robert Louis Stevenson High School in Pebble Beach, California, received the AMS second-place award of $\$ 100$ for her project "Comparison of Acidity in Ambient Air and Rain." Lantis studied moisture samples collected over a two-year period (December 1989-April 1991) for both normal fog/stratus conditions and rain from passing synoptic storms affecting the Monterey peninsula. She built rain catchment devices and studied moisture samples using a $\mathrm{pH}$ meter and chart recorder in concert with a fraction collector advancing at 15-min intervals. To trace possible pollution sources, she monitored circulation patterns affecting the West Coast using surface charts provided by the meteorology department at the U.S. Naval Postgraduate School. 


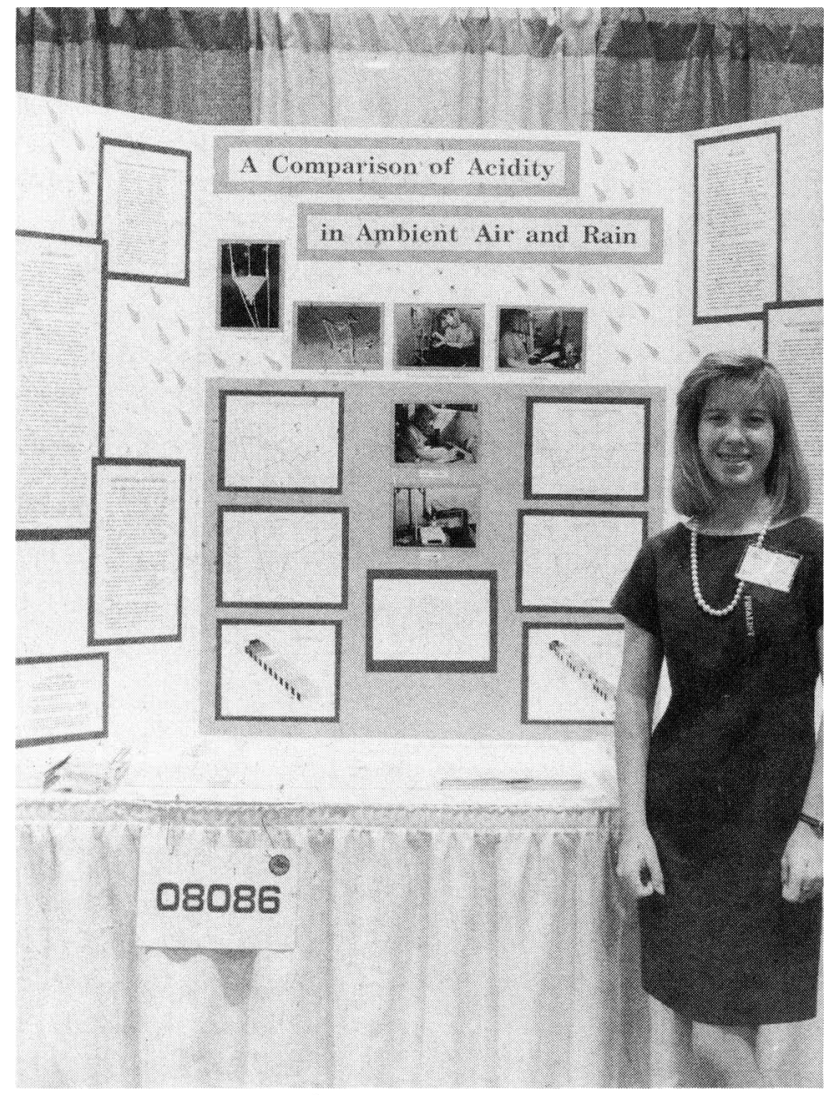

Amy Lantis is AMS second-place award winner of the International Science and Engineering Fair for her project, "Comparison of Acidity in Ambient Air and Rain."

Lantis' findings show that acidic precipitation $(\mathrm{pH}$ lower than 5.6) accompanies landfalling marine cyclonic storms. This is in contrast to moisture samples collected from fog/stratus under stable conditions that yield values of minimal acid content $(\mathrm{pH}$ averaging near 6.0). Lantis' analysis suggests that air trajectories accompanying the storm circulation patterns pass over major urban centers. These potential pollution sources, such as San Francisco and Los Angeles, inturn, influence precipitation acidity.

Honorable Mention Award: Timothy W. Thomas, 15, a sophomore at Marion High School in Marion, South Carolina, received the book Spacious Skies from AMS headquarters for honorable mention standing in the ISEF. His project "Weather Forecasting: Is It Possible to Develop a Systematic Forecasting Center from Observed Weather Variables Taken at Set Intervals of Time?" examined multiple correlations between observations of atmospheric variables such as pressure, wind direction/speed, and sky conditions in Marion. Thomas developed relationships between these variables for a local 24-hr weather prediction scheme. In addition, Thomas' striking photography of

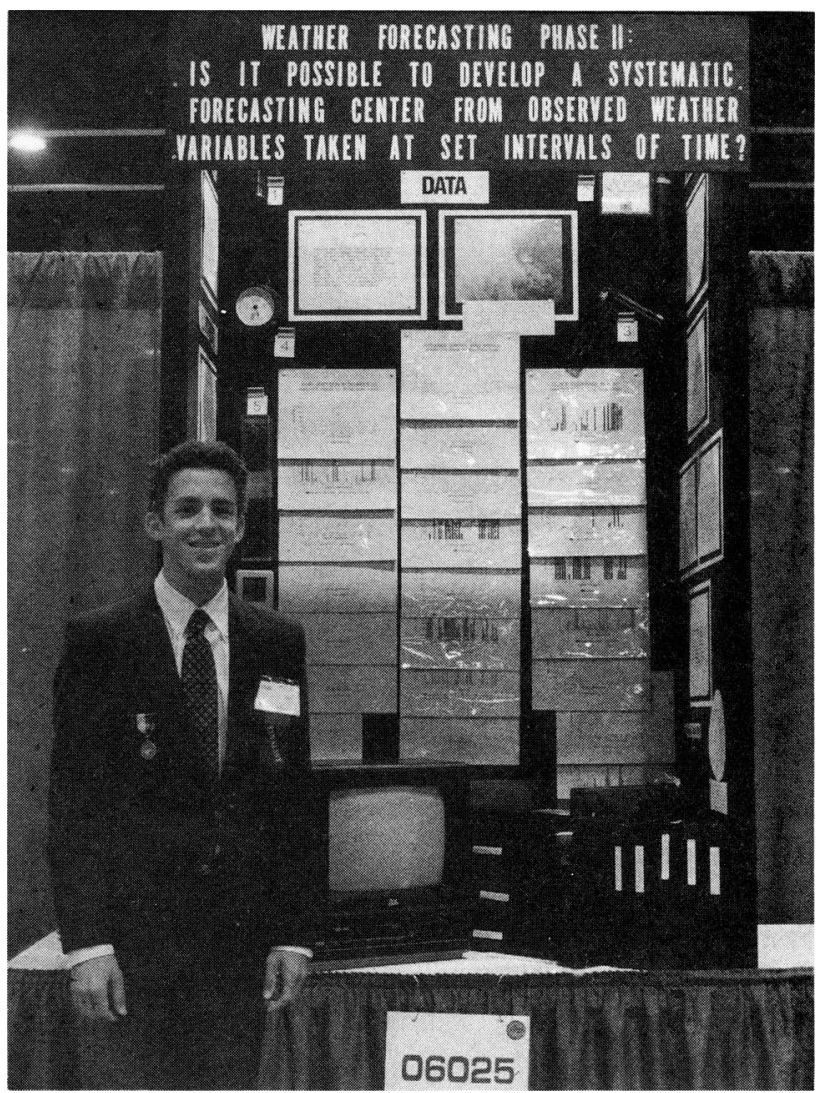

Timothy $\mathrm{W}$. Thomas received honorable mention at the AMS International Science and Engineering Fair for his project on weather forecasting.

various cloud classifications won him an honorablemention recognition from the Eastman Kodak judges.

\section{Summary of State-by-State Science Fair Activity}

\section{Western New York}

The 29th Annual Niagara Regional Science and Engineering Fair was held at Brock University in St. Catharines, Ontario, from 8 to 11 April 1991. Judging was conducted on 9 April by Brian Taylor and George Thorpe, science teachers with the Lincoln County (Ontario) Board of Education. Taylor and Thorpe represented the Western New York chapter, the local chapter of the AMS.

The cowinners of the fair, Benjamin Papp and Matthew Blakely, attend St. Alexander's elementary School in Fonthill, Ontario. Their winning entry was entitled "Hurricanes."

At the awards ceremony, which was conducted at the Centennial Secondary School in Welland, Ontario, on 17 April, the two students were presented with AMS certificates by Greg Finn, a professor at Brock University. 


\section{Omaha-Offutt}

The Omaha-Offutt chapter provided judges for the Greater Nebraska Science and Engineering Fair held in Nebraska City, Nebraska, on 6 April 1991. John Zapotocny and Richard Ferris awarded a subscription to Weatherwise magazine to Megan Obermueller of Seaward, Nebraska, for her exhibit "Solar Energy Transfer via Phase Change." Evan Friesen of Henderson, Nebraska, won a weather radio for his entry "Blade Patterns for a Wind Charger." Joey Crum of Brainard, Nebraska, presented his project "How Many Blades? How Much Current?" and received a Weatherwise subscription. Jessee Slosser's (of Bellwood, Nebraska) exhibit "Wind and Energy" earned him a copy of $A$ Field Guide to the Atmosphere. Becky Bennett of Nebraska City, Nebraska, was recognized for the "Amount of Acid in Nebraska's Rain" and received The American Weather Book. All award recipients also received copies of the Heartland Weather Calendar.

Chapter members also participated in the Hawkeye Science and Engineering Fair held in Des Moines, lowa, on 6 April 1991.

Jay Albrecht, Vicki Babcock, and Mike Babcock reviewed 11 projects relating to atmospheric science. Winners included Josh Mishoe of Van Meter, lowa, for "What Causes Tornadoes and Hurricanes?"; he received a weather radio for his effort. Lori Tastad of Fonda, lowa, received The American Weather Book for her presentation "Hurricanes." Amy Dreyer of Farragut, lowa, was awarded A Field Guide to the Atmosphere for her entry "Permanent Snow." Weatherwise subscriptions were given to Amy Millmier of Donnellson, lowa, who presented "The Greenhouse Effect: What on Earth Are We Doing?" and Travis Arndorfer of Algona, lowa, for his exhibit "Acid Rain and lowa Crops."

\section{New York/Long Island}

Chapter representatives judged the Queens Science Fair on 9 March and the 53rd Citywide New York City Science Fair held in Manhattan on 8 April.

A Certificate of Outstanding Achievement for Ability and Creativity in an Atmospheric Science Exhibit was awarded to Hau Cai from John F. Kennedy High School of the Bronx for his project entitled, "High Efficient Vertical Axis (HEVA) Wind Turbine."

His results indicated that the HEVA wind turbine with stationary airfoil-shaped blades at a blade angle of $40^{\circ}$ and a central angle of $10^{\circ}$ was most efficient. Compared to the horizontal axis windmill, the HEVA wind turbine produced electricity two times greater than the power output of the horizontal-axis windmill at low wind velocity, and $64 \%$ more efficiently at high wind velocity.

\section{Gulf Coast}

The Gulf Coast chapter of the American Meteorological Society was proud to have participated in the Greater New Orleans Science and Engineering Fair on 5 March 1991. WVUE-TV meteorologist Bob Breck represented our chapter as judge at the fair, awarding a one-year subscription to Weatherwise for the best exhibit in the field of meteorology in both the junior and senior divisions, and two Outstanding Achievement awards. Brandi Barrois won an Outstanding Achievement award for the project "Can Weather Be Predicted Accurately?" Ashley Braniff won an Outstanding Achievement award for the project "What Causes the Winds?" Heather Mains won the Weatherwise subscription for the project "What Effect Does Acid Rain Have on Plants?"

\section{Denver-Boulder}

The Denver-Boulder chapter sent judges to three science fairs and one science olympiad this year.

At the local level, several members attended the Denver Metropolitan Science Fair on 18 March 1991 at the Colorado School of Mines in Golden, Colorado. An AMS certificate was awarded in the junior division to Eric Berson for his entry "How Accurate is Weather Prediction?" In the senior division, Thinh Cao won with "The Effect of Particulate Matter on the Transmission of Ultraviolet Radiation."

The Boulder Valley Science Fair was held on 8 March. Chapter president Ron Hollee gave out two certificates. One was given to Lisa Been, who investigated "Helium Changes in Soil Gas over a 24-hr Period." The other was awarded to Paul Bovis for recording "Snowmelt in Table Mesa."

The Colorado State Science Fair was held on 11 April 1991 at Colorado State University in Fort Collins. Chapter secretary Tracy Lorraine Smith awarded AMS certificates in the junior and senior divisions. The senior division winner, Teresa Koper of Silt, Colorado, exhibited "The Effect of Carbon Dioxide on Ambient Air Temperature." The recipient in the junior division was Christine Kruse of Littleton for her entry, "The Construction and Application of an Air-Heating Solar Collector."

\section{Miami}

The Miami chapter of the AMS assisted in judging competitors in the 17th Annual Broward County Science Fair on 12 February 1991. In the Middle School Division, Jessica Rayson from Pompano Beach Middle School was selected as the winner and Sarah Gruen of Parkway Middle School received honorable mention. In the high-school division, Gennaro Calabrese of Nova High School was the winner and Claire Carlson from Boyd Anderson High School received honorable mention. Sim Aberson and Howie Friedman served as 
judges, and Christopher Burr presented a certificate and cash award to the winners.

\section{Greater Kansas City}

The Mid-American Science and Engineering Fair was held at Missouri Western State College in St. Joseph, Missouri, on 22 March. Dave Cokely judged the fair and selected two projects to receive AMS Certificates of Recognition. Nikki Miljavic, a junior at LeBlond High School in St. Joseph, won for a project entitled "Air Pollution During Temperature Inversions." She created an inversion in a bell jar by shining a heat lamp over a pool of ice water. Smoke was trapped in the stable layer between the surface of the water and the heated air at the top of the jar. An associated paper highlighted problems caused when such inversions form over cities. Chris Mell, also a junior at LeBlond High School, won for a project entitled "Pollutants in Rain Water." He had collected precipitation samples from in and around St. Joseph. He then measured the $\mathrm{pH}$ of the samples and tried to relate the results to various sources of pollution.

The Greater Kansas City Science and Engineering Fair was held in Kansas City, Missouri, on 11-12 April. Beverly Poole, Ken Rizzo, Dave Cokely, and Joe Schaefer judged the event. Winning the intermediate category (elementary school) was an exhibit entitled "Predicting the Weather" by Nicholas Krueger, a fourthgrade student at Gladden School in Belton, Missouri. His project entailed the constructing of a rather full array of homemade instruments (a thermometer, a barometer, and an anemometer). He made daily observations and attempted to forecast the next day's weather. The junior category (junior level) prize was won by Elise Romo, a seventh-grader at Highland Middle School in Kansas City, Kansas. Her project consisted of a rather unique forecast contest. She took daily observations before and after school. She used these observations and the weather map from the newspaper to make a forecast for the next day. She then watched the evening news (always from the same channel) and recorded the professional meteorologist's prediction and performed a comparative verification of the two sets of forecasts.

\section{Sacramento}

The Sacramento chapter participated in the 38th Annual California Central Valley Science and Engineering Fair that ran 8-12 April 1991. This fair was held in Sacramento and was sponsored by the Sacramento Bee newspaper, California State University at Sacramento, University of California at Davis, and Sacramento Science Center. Chapter members Cary McGregor, Richard Hackney, and Freemen Smith reviewed over 1500 exhibits entered.
We presented Rageshree Ramachandran the AMS award for outstanding achievement in atmospheric science for his project, "A Chaotic Model for the El Niño-Southern Oscillation." She was also named the grand winner in the senior division and was selected to compete in the International Science and Engineering Fair in Orlando, Florida. There, she went on to win third place in the Earth and Space Science category and receive awards from the American Mathematical Society and NOAA. The NOAA award allowed her to participate in the London International Youth Science Fortnight (July 1991). The following fair entrants received honorable mentions from our chapter: Robert Garfinkel for his project "Acid Precipitation: Phase III Acid Snow Determination of Sulfuric Acid and Nitric Acid Pollution Levels of 1991 High Sierra Snowpack Utilizing Ionic Chromatography"; Scott Hulbert for "Cloud Effects on Atmospheric Temperature Variation"; Joanne Gifford for "Is Air Temperature Warmer in the Morning, Early Afternoon or Late Afternoon?"; Jennifer Lazar for "Percent Oxygen in Air"; and Michael Quist for "Does the Weather Affect Chickens?"

\section{Sioux Falls}

The Sioux Falls chapter of the AMS contributed two cash awards on 4 April 1991 to the area's science fair, held in Brookings, South Dakota. The first-place award was presented to Karla Kieckhefer for an excellent project that tested the "Effect of Vegetation on Soil Temperature." Temperature data were gathered during several months over different vegetation in the student's yard. This project, the student's third of a series of related, excellent science fair projects, showed a lot of effort, knowledge, andgood experimental design.

The second-place award went to Debbie Huss for her display on "What Causes Wind to Blow." The display showed some good research and interest.

An honorable mention went to Justin Meyer for his display titled "Weather." Justin showed a developing interest that will hopefully lead to more specific studies and research in the future. Judges were Steve Eddie and Clifford Millsapps from the National Weather Service in Sioux Falls.

\section{North Texas}

The 1991 Dallas Morning News-Toyota Regional Science and Engineering Fair attracted more than 400 participants in the junior and senior high school categories. North Texas AMS chapter president William O. Alexander, vice president Melvin McLaughlin, and secretary-treasurer Cynthia Abelman served as judges. Although entries relating to meteorology and/or the earth sciences were scarce in the senior division, a number of commendable entries were noted in the junior division. 
The first-place winner in the junior division was a remarkable project on weather lore by 12 -year-old Kevin Bernhart of Dallas. Kevin collected a large number of old weather sayings and researched their origins. It turned out that many of the old sayings were not accurate because they were transported from their original niche. When placed back into their land of origin, the sayings were again accurate. The secondplace winner was a project on ozone and CFCs by 13year-old Gene Finney, also of Dallas. Finney's work was scientific, as well as researched with a nice display of the facts. Third place went to a study of automobile exhaust and acid rain, ingeniously presented and finely detailed by 14 -year-old Hank Fore of Addison. In the senior division, an honorable mention was given to Hae Jung Moor of Dallas for her presentation of "Gone with the Wind," a well-researched climatology of North Texas wind.

\section{Utah}

The winners of the North Weber Area Science and Engineering Fair were Karina Thorpe for her project "Solar Refraction" and Brian and Matt Jones for their project "Tidal Powers." The North Davis Area Science Fair winners were Greg Taylor for his project "Clouds:
The Ultimate Refreshment," Jason France for "Weather Station," and Justin Caldwell for "Temperature Inversion Hypothesis." The 24th Annual Roy Area Science and Engineering Fair winner were Jaimee Ellis and Sarah Simpson for their Project "Clouds." The winners of the State Science and Engineering Fair held on 25 March 1991 were Tricia Kingsbury for "Acid Rain" and Tyler Jensen for "Air Pollution in Residential Areas." The winners of the State Science and Engineering Fair held on 27 March 1991 were Karina Thorpe for her project "Atmospheric Refraction," Lincoln Nadauld for "The Deteriorating Effects of Acid Rain," and Nicole Barber for "The Effects of Acid Rain on Plant Life." The Color County Utah Science and Engineering Fair winners were Cameron Christenson for "Comparative Energy Consumption" and Aimee Faucheux for "Does Windchill Affect Home Heating?" The Southeastern Utah Regional Science and Engineering Fair winner wasTonya Leavitt. She received an AMS Certificate of Achievement as a category winner in the Earth and Space Science Division. The winners of the Central Utah Science and Engineering Fair were Peter Chudleigh for "Weatherman vs. Amateurs," and Victoria Farnsworth and Melia Turnblom for "Clouds."

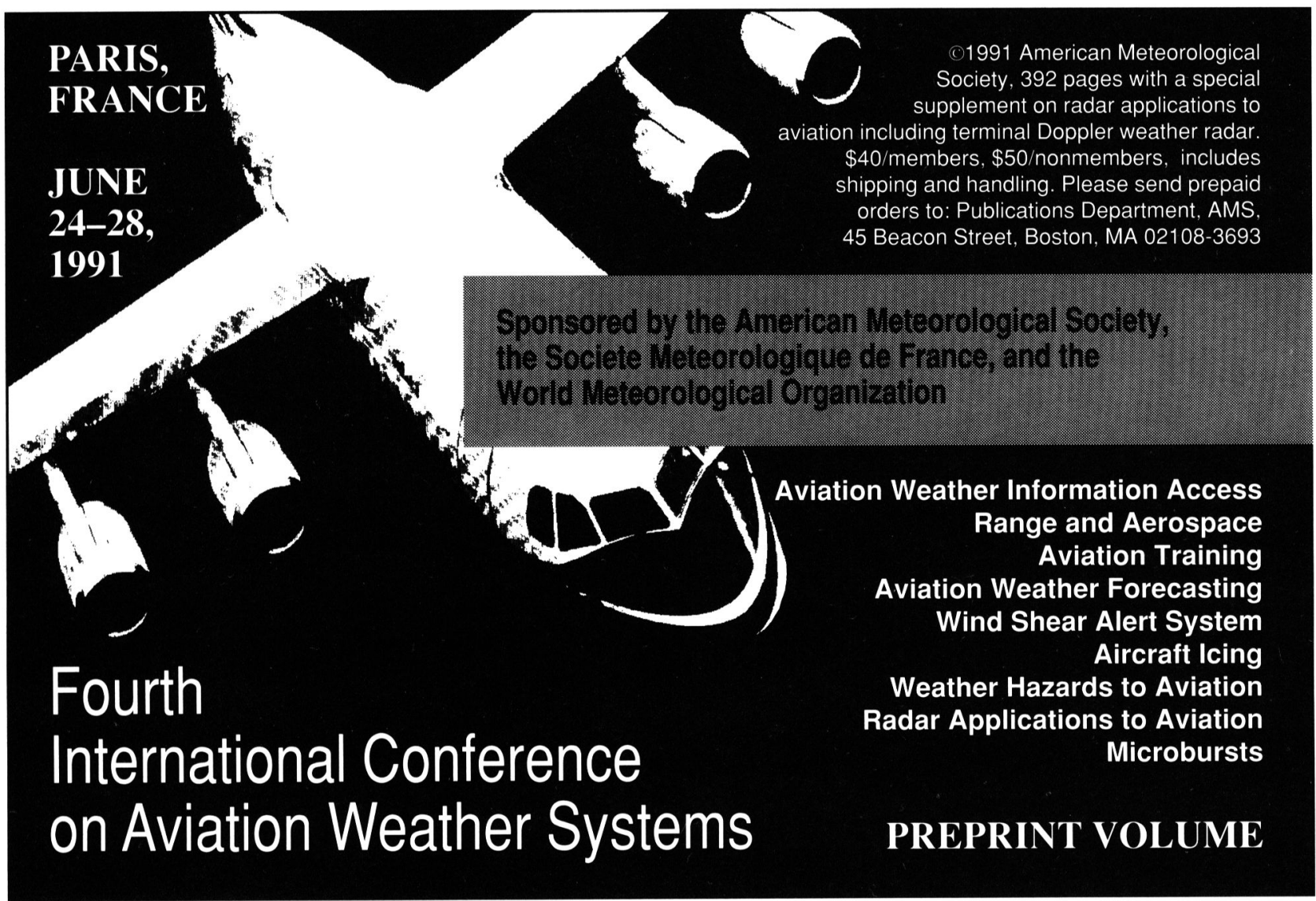

